\title{
U
}

\section{Sistem Tujuan Konsumen Pada Tawaran Berhutang}

\begin{abstract}
Debt and no debt behavior is the instrument to pursuit goals. Almost all of behavior is goal-directed including debt and no debt behavior. The objective of this research was to find goals of debt and no debt behavior and to know hierarchical structure of these goals that organized on goal system. Laddering technique was used to explore goals of consumer that receive and refuse debt. This technique used to find consumers goals that organized hierarchically that consist of action goal, focal goal, and superordinate goal. Open-ended questionnaire was developed based on laddering technique questions. Demography form was added to explore demography data. One hundred four respondents participated in this research. Participants are teachers and staffs in elementary and middle school. Content analysis was applied to all responds to analyze and categorize laddering data. From 104 respondents, there are 50 respondents receiving debt and 54 refusing debt. Total goals of consumers that receive debt are 720 and 383 for respondents that refuse debt. Result of content analysis show that action goals of consumers receiving debt are to invest, for housing, for children, for education, for appliance, secondary need, and to save. On the focal goals level, the most goals mentioned were economic established, self quality, children competency, having quality home, family harmony, improve life, prepared motive, and social motive. On the highest level, super-ordinate goals of consumer receive debt were dominated by productivity and efficiency, followed by happiness and spirituality. While for consumer refusing debt, action goal was refuse debt. On the Focal goal level, the frequently goal mentioned were being free of debt, hassle free, prudence, repay debt first, and just enough. Finally, super-ordinate goals of consumer refuse debt were dominated by comfortable life followed by happiness and spirituality. There were three demography variable that can be differentiated the choice receiving debt or refusing debt namely: age, job status, and ever or never taking debt on ten last years.
\end{abstract}

KEYWORDS: consumer goal, consumer receiving debt, consumer refusing debt, laddering.

Muh. Untung Manara

Alumnus Program Pascasarjana Fakultas Psikologi Universitas Gadjah Mada Yogyakarta

Rahmat Hidayat

Dosen Fakultas Psikologi Universitas Gadjah Mada Yogyakarta

Email: manara_mu@yahoo.com 
Hutang merupakan salah satu kebijakan ekonomi modern agar perekonomian tetap berlangsung. Dengan tidak adanya penyaluran kredit, maka dunia bisnis dan usaha tidak berjalan dan proses produksi barang dan jasa akan berhenti. Dengan rendahnya produksi barang dan jasa, maka permintaan tidak sesuai dengan penawaran. Di sisi lain penyaluran kredit konsumsi juga diperlukan agar membantu meningkatkan daya beli masyarakat untuk mengkonsumsi barang dan jasa yang diproduksi.

Untuk mengatasi permasalahan ini, pihak pemberi kredit harus mempertimbangkan pemberian kredit tersebut agar tidak terjadi kredit bermasalah. Pihak kredit harus melakukan analisis terhadap pihak debitur yang akan berhutang supaya kredit macet dapat dihindari. Dalam dunia perbankan dikenal kerangka 6C's, (character, capacity, capital, collateral, conditions, constraint) dalam rangka menganalisa calon kreditur untuk mencegah terjadinya kredit bermasalah (Rivai, dkk., 2007).

\section{Kerangka Kerja Teoritik}

Character merupakan sifat dan watak calon kreditor. Ini merupakan faktor psikoligi yang berkontribusi pada perilaku kredit dari individu yang akan berhutang. Hal ini penting untuk diketahui, karena dapat memengerahui keputusan untuk dapat memberikan kredit atau tidak. Pihak bank harus memahami karakter calon kreditur menyangkut apakah kreditur seseorang yang dapat dipercaya. Faktor psikologi yang diistilahkan character pada prinsip penyaluran kredit perbankan merupakan faktor yang menentukan perilaku kredit seseorang. Faktor ini penting untuk diketahui karena setiap perilaku individu tidak terlepas dari sisi psikologisnya. Berbagai penelitian menunjukkan bahwa faktor psikologi berperan penting pada perilaku berhutang dan pilihan berhutang atau tidak (Prasadjaningsih, 1998; Lea, dkk., 1995; Nyhus \& Webleyn, 2001; Alhassan, dkk., 2007; Watson, 1998).

Penelitian tentang hutang dari perspektif kajian psikologi sudah banyak dilakukan. Hutang mempunyai hubungan yang timbal balik dengan faktor psikologi. Penelitian Watson (1998) menunjukkan individu yang mempunyai nilai materialism yang tinggi mempunyai sikap yang lebih positif terhadap hutang. Sedangkan Prasadjaningsilł (1998) menemukan bahwa konsumen yang berhutang lebih mancerminkan keprizadian ekstrovet yang 
bersifat impulsif, berfikir praktis, dan cenderung memakai konsep felksibel. Sedangkan konsumen yang tidak berhutang menampilkan kepribadian introvet yang cenderung banyak pertimbangan, terkendali dan kaku. Dukungan sosial yang diterima individu juga signifikan berhubungan dengan pilihan berhutang seseorang. Wang \& Xiao (2009) menemukan bahwa semakin tinggi dukungan sosial seseorang semakin sedikit hutang kartu kredit yang dimiliki mahasiswa di Amerika di mana kartu kredit sudah menjadi trend gaya hidup anak muda.

Dari berbagai penelitian hutang dari kajian psikologi belum terdapat penelitian yang mengkaji lebih jauh tentang motiv dan tujuan dari perilaku berhutang seseorang. Sementara motivasi dan tujuan merupakan faktor yang berkontribusi penting pada setiap perilaku individu. Tujuan merupakan salah satu faktor penting di balik perilaku seseorang. Dalam kajian psikologi terdapat beberapa faktor di balik sebuah perilaku yaitu faktor internal, proses psikologi, dan faktor eksternal. Tujuan adalah salah satu faktor internal yang memotivasi seseorang berperilaku tertentu (Job \& Brandstätter 2009). Memahami seseorang berarti memahami tujuannya. Carver (2003) menjelaskan bahwa hidup merupakan proses yang berkelanjutan dalam mencapai tujuan dan bentuk penyesuaian dari perilaku untuk menjadikan tujuan menjadi kenyataan. Dari berbagai teori tentang tujuan, semuanya menekankan bahwa tujuan memberikan daya dan mengarahkan aktivitas seseorang. Setiap perilaku merupakan perilaku yang diarahkan oleh tujuan (goal directed) (Carver \& Scheier, 1998).

Dari sini penting untuk melakukan penelitian tentang tujuan-tujuan konsumen terkait hutang. Selain itu juga penting untuk meneliti perilaku individu yang menolak tawaran hutang sebagai salah satu sikap yang mungkin memandang negatif perilaku berhutang. Jadi pertanyaan pertama dari penelitian ini adalah: "tujuan-tujuan apa saja yang dimiliki oleh individu yang melakukan perilaku berhutang dan perilaku menolak hutang?"

Tujuan mempunyai sistem yang bersifat berjenjang. Dari level abstraksi, tujuan dapat dibedakan dari yang bersifat abstrak hingga tujuan yang lebih konkrit (Carver \& Scheier, 1998). Tujuan yang bersifat abstrak mempunyai hubungan dengan tujuan di bawahnya yang lebih kongkrit. Hubungan tujuan dari tingkatan yang lebih tinggi menuju tingkatan yang debjik rendah terorganisasi dalam tingkatan level abstraksi. Hierarki lnvel tujuan sudalobangak dikaji dalam, 
rangka melihat motiv dibalik sebuah perilaku. Tingkatan tujuan ini dapat dijelaskan melalui skema yang digambarkan melalui bentuk tingkatan berjenjang dan saling berkaitan. Bagozzi dan Dholakia (1999) mengklasifikasikan tingkatan hierarkis tujuan menjadi tiga yaitu: action goal, focal goal, dan super-ordinate goal.

Salah satu pendekatan dalam mengkaji organisasi hierarkies tujuan dan saling keterkaitannya adalah teori sistem tujuan (Kruglanski, dkk., 2002). Sistem tujuan merupakan representasi mental dari jejaring motiv (motivational networks) yang terdiri atas berbagai tujuan dan saling keterkaitannya dengan cara pencapaian tujuan. Dari analisa sistem tujuan dapat terlihat bentuk hubungan antar tujuan. Seberapa sering suatu tujuan menjadi alat atau instrument untuk mencapai tujuan lainnya, tujuan apa yang menjadi sumber atau akhir dari tujuan yang lain, atau seberapa besar keterlibatan tujuan dalam jaringan sistem sosial merupakan bentuk hubungan antar tujuan yang bisa dilihat dalam sistem tujuan. Dari teori tentang hierarki tujuan, pertanyaan penelitian kedua dari penelitian ini yaitu "bagaimana keterkaitan antar tujuan-tujuan konsumen berhutang maupun menolak hutang yang terorganisir dalam sebuah sistem tujuan?"

\section{Metode}

Penelitian ini merupakan penelitian desktiptif dengan menggunakan teknik leddering procedure yang dapat dikategorikan sebagai pendekatan konstruktivisme / kualitatif yang mengungkap tujuan-tujuan konsumen dari perspektif konsumen. Teknik laddering digunakan dalam berbagai penelitian dalam rangka mengungkap struktur hierarkis tujuan di balik perilaku individu (Bagozzi \& Dholakia, 1999; Reynolds \& Guttman, 1988; \& Neimeyer, dkk., 2001).

Responden berjumlah 104 yang terdiri dari guru dan staff pada sekolah dasar dan menengah di Yogyakarta dan sekitarnya. Pemilihan guru sebagai responden penelitian dengan pertimbangan guru mempunyai pendapatan dan karir yang stabil dari masa awal karir hingga usia memasuki masa pensiun. Pemilihan subjek dilakukan dengan nonrandom sampling, dengan demikian berarti bahwa besarnya peluang anggota populasi untuk terpilih sebagai sampel tidak dapat diketahui (Azwar, 2007).

Metode pengưniptilalitidata pada penelitian ini menggu- 
nakan angket yang diadaptasi dari generic-goal laddering questionnaire yang dikembangkan Hidayat (2009). Selain pertanyaan laddering, instrumen ini juga menungkap data demografi responden yaitu umur, jenis kelamin, pekerjaan, pendapatan, jumlah anak, dan pendidikan. Variabel-variabel demografi ini digunakan dalam rangka untuk memperkaya data dan digunakan untuk menganalisa kecenderungan pilihan menerima atau menolak tawaran berhutang berdasarkan demografi.

Sebelum masuk pada tahapan analisa data laddering, pertama-tama yang dilakukan adalah memisahkan jawaban responden yang menerima tawaran berhutang dan yang menolak. Untuk melihat seberapa besar variabel demografi dapat membedakan kecenderungan berhutang atau tidak digunakan analisis dekskriptif tabulasi silang (crosstab analysis). Masing-masing kelompok yang menerima dan menolak kemudian dianalisa secara terpisah dengan menggunakan prosedur analisa pada teknik laddering .

Prosedur analisis data laddering digunakan untuk melihat struktur hierarki tujuan dalam sistem tujuan. Terdapat lima tahapan proses analisis data pada teknik laddering yaitu content analysis, implication matrix, cut off level, index prominence, dan hierarchical goal map (Reynolds \& Gutman, 1988; Bagozzi, dkk., 2003; \& Pieters, dkk., 1995; \& Hidayat, 2009).

\section{Hasil}

\section{Analisis tabulasi silang variabel demografi terhadap pilihan menerima/ menolak hutang}

Dari hasil analisis tabulasi silang antara variabel-variabel demografi dengan pilihat berhutang atau tidak menunjukkan terdapat 3 variabel yang secara signifikan dapat membedakan kecenderungan manerima atu menolak hutang, yaitu usia, pekerjaan, dan pernah berhutang atau tidak selama sepuluh tahun terakhir. Dari persentase menerima dan menolak tawaran hutang, terlihat bahwa semakin tua responden, maka semakin rendah kecenderungan berhutang, demikian juga sebaliknya. Nilai chi-square $0.008<0.01$ dimiliki varibel pekerjaan, yang menunjukkan bahwa terdapat perbedaan yang sangat signifikan antara PNS, honorer, dan guru swasta terkait dengan kecenderungan menerinfa atau mithenolak tawaran hutang. Honorer 
mempunyai persentase tertinggi dalam menerima hutang yaitu $66.7 \%$, diikuti oleh PNS sebesar 48.6, dan guru swasta mempunyai kecenderungan berhutang sangat rendah, yaitu hanya $9.1 \%$ yang menerima dari keseluruhan total guru swasta yang ada.

Table 1. Perilaku menerima/menolak hutang berdasarkan demografi

\begin{tabular}{|c|c|c|c|c|c|c|c|}
\hline \multirow{2}{*}{ Demografi } & \multicolumn{2}{|c|}{ Terima } & \multicolumn{2}{|c|}{ Tolak } & \multicolumn{2}{|c|}{ Total } & \multirow{2}{*}{$\begin{array}{c}\text { Pearson Chi- } \\
\text { Square }\end{array}$} \\
\hline & Frek. & $\%$ & Frek. & $\%$ & Frek. & $\%$ & \\
\hline \multicolumn{8}{|l|}{ Jenis kelamin } \\
\hline Laki-laki & 27 & 57.4 & 20 & 42.6 & 47 & 100 & \\
\hline Perempuan & 23 & 40.4 & 34 & 59.60 & 57 & 100 & 0.082 \\
\hline Total & 50 & 48.1 & 54 & 51.9 & 104 & 100 & \\
\hline \multicolumn{8}{|l|}{ Usia } \\
\hline$<35$ th & 23 & 65.7 & 12 & 34.3 & 35 & 100 & \\
\hline 35 th -55 th & 24 & 40.7 & 35 & 59.3 & 59 & 100 & 0.031 \\
\hline$>55$ th & 3 & 30 & 7 & 70 & 10 & 100 & \\
\hline Total & 50 & 48.1 & 54 & 51.9 & 104 & 100 & \\
\hline \multicolumn{8}{|l|}{ Jumlah anak } \\
\hline 0 & 15 & 60.0 & 10 & 40.0 & 25 & 100 & \\
\hline 1 & 13 & 46.4 & 15 & 53.6 & 28 & 100 & \\
\hline 2 & 15 & 48.4 & 16 & 51.6 & 31 & 100 & 0.419 \\
\hline$<3$ & 7 & 35.0 & 13 & 65.0 & 20 & 100 & \\
\hline Total & 50 & 48.1 & 54 & 51.9 & 104 & 100 & \\
\hline \multicolumn{8}{|l|}{ Pendidikan } \\
\hline SMP & 1 & 50.0 & 1 & 50.0 & 2 & 100 & \\
\hline SMA & 6 & 50.0 & 6 & 50.0 & 12 & 100 & \\
\hline $\begin{array}{l}\text { Sarjana/ } \\
\text { Diploma }\end{array}$ & 27 & 40.3 & 40 & 59.7 & 67 & 100 & 0.117 \\
\hline Pascasarjana & 16 & 69.6 & 7 & 30.4 & 23 & 100 & \\
\hline Total & 50 & 48.1 & 54 & 51.9 & 104 & 100 & \\
\hline \multicolumn{8}{|l|}{ Pekerjaan } \\
\hline PNS & 35 & 48.6 & 37 & 51.4 & 72 & 100 & \\
\hline Honorer & 14 & 66.7 & 7 & 33.3 & 21 & 100 & 0.008 \\
\hline Swasta & 1 & cle & with & 90.9 & 11 & 100 & \\
\hline
\end{tabular}




\begin{tabular}{lccccccc} 
Total & 50 & 48.1 & 54 & 51.9 & 104 & 100 & \\
Jabatan & & & & & & & \\
Guru & 45 & 48.4 & 48 & 51.6 & 93 & 100 & \\
Staff & 5 & 45.5 & 6 & 54.5 & 11 & 100 & 0.854 \\
Total & 50 & 48.1 & 54 & 51.9 & 104 & 100 & \\
Pendapatan & & & & & & & \\
$<1$ jt & 6 & 42.9 & 8 & 57.1 & 14 & 100 & \\
1 jt -2 jt & 14 & 51.9 & 13 & 48.1 & 27 & 100 & \\
2 jt -3 jt & 12 & 44.4 & 15 & 55.6 & 27 & 100 & 0.915 \\
3 jt -4 jt & 10 & 55.6 & 8 & 44.4 & 18 & 100 & \\
$>4$ jt & 8 & 44.4 & 10 & 55.6 & 18 & 100 & \\
Total & 50 & 48.1 & 54 & 51.9 & 104 & 100 & \\
Pernah & & & & & & & \\
berhutang & & & & & & & \\
Pernah & 48 & 53.3 & 42 & 46.7 & 90 & 100 & \\
Tidak & 2 & 14.3 & 12 & 85.7 & 14 & 100 & 0.007 \\
Total & 50 & 48.1 & 54 & 51.9 & 104 & 100 & \\
\hline
\end{tabular}

\section{Analisis data laddering}

Dari 104 responden, 50 responden yang menerima hutang dan 54 responden menolak hutang. Dari 50 responden menerima hutang menyebutkan 720 tujuan sebagai alasan menerima hutang dan terdapat 451 hubungan antar tujuan. Sedangkan 54 responden yang menolak hutang menyebutkan 383 tujuan sebagai alasan mengapa menolak hutang dan terdapat 176 hubungan antar tujuan.

Untuk menyederhanakan tujuan-tujuan yang diberikan responden, analisis isi digunakan dalam rangka mengkategorikan data. Tiga mahasiswa program magister psikologi mengkategorikan data berdasarkan panduan koding yang disusun berdasarkan teori dan penelitian sebelumnya terkait dengan tujuan konsumen (Hidayat, 2009; \& Katona, 1975). Setiap coder diberikan lembar yang berisi keseluruhan tujuan dari responden yang berjumlah 104 dan panduan koding di atas. Setelah dilakukan koding dari ketiga coders, ketiga versi koding data dikumpulkan untuk kemudian dilihat tingkat kesepahaman. Dari keseluruhan respon tujuan yang ada terdapat 
163 atau $15.5 \%$ koding tujuan yang berbeda dari ketiga koder. Hal ini menunjukkan tingkat kesepahaman dari proses koding mencapai $84.5 \%$. Koding yang tidak sama tersebut didiskusikan antara ketiga coder untuk mendapatkan kesepahaman.

Untuk melihat struktur hierarki dan keterkaitan tujuan dalam sebuah organisasi sistem tujuan langkah pertama adalah dengan membuat implication matrix (lampiran). Implication matrix menunjukkan frekuensi hubungan antar dua tujuan. Pada implication matrix, tujuan yang tersusun secara horizontal menunjukkan tujuan sebagai sasaran, sedangkan tujuan yang tersusun vertikal menunjukkan tujuan sebagai asal dari tujuan yang lain. Seberapa sering suatu tujuan dijadikan sebagai sasaran dapat dilihat dari total jumlah pada baris terakhir yang disebut in-degrees. Sedangkan seberapa sering suatu tujuan menjadi asal dari tujuan-tujuan yang lain dapat dilihat pada total jumlah kolom terakhir yang disebut outdegrees.

Selanjutnya, implication matrix digunakan sebagai landasan untukmembuat peta tujuan hierarkis (hierarchical goal map), selanjutnya disingkat HGM. HGM merupakan gambaran yang menunjukkan berbagai hubungan antar tujuan yang terdapat pada implication matrix. Apabila semua hubungan antar tujuan ini digambarkan dalam HGM, maka gambar akan terlihat tidak beraturan, karena terlalu banyak garis yang menunjukkan hubungan antar tujuan. Untuk itu diperlukan batasan minimal tingkat hubungan yang akan digambarkan pada HGM. Pada prosedur analisis data laddering, tidak ada rumusan yang mengikat dalam rangka menentukan batasan minimal ini. Namun untuk pertimbangan ketercakupan data ketika mengambil batasan minimal, pada umumnya dibuat cut-off level. Sebagai contoh penelitian Bagozzi, dkk., (2003) mengambil cut-off 7 yang berarti hanya hubungan yang mempunyai frekuensi minimal 7 yang akan digambarkan pada HGM. Adapun pada penelitian ini menggunakan cutt-off level 4 untuk HGM secara keseluruhan dan HGM responden yang menerima tawaran hutang. Sedangkan untuk responden yang menolak hutang menggunakan cut-off 3. Gambar 2, 3, dan 4 menunjukkan peta tujuan hierarkis (HGM) dari responden menerima/menolak hutang dan gabungan dari keseluruhan responden.

\section{Created with

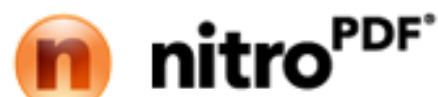




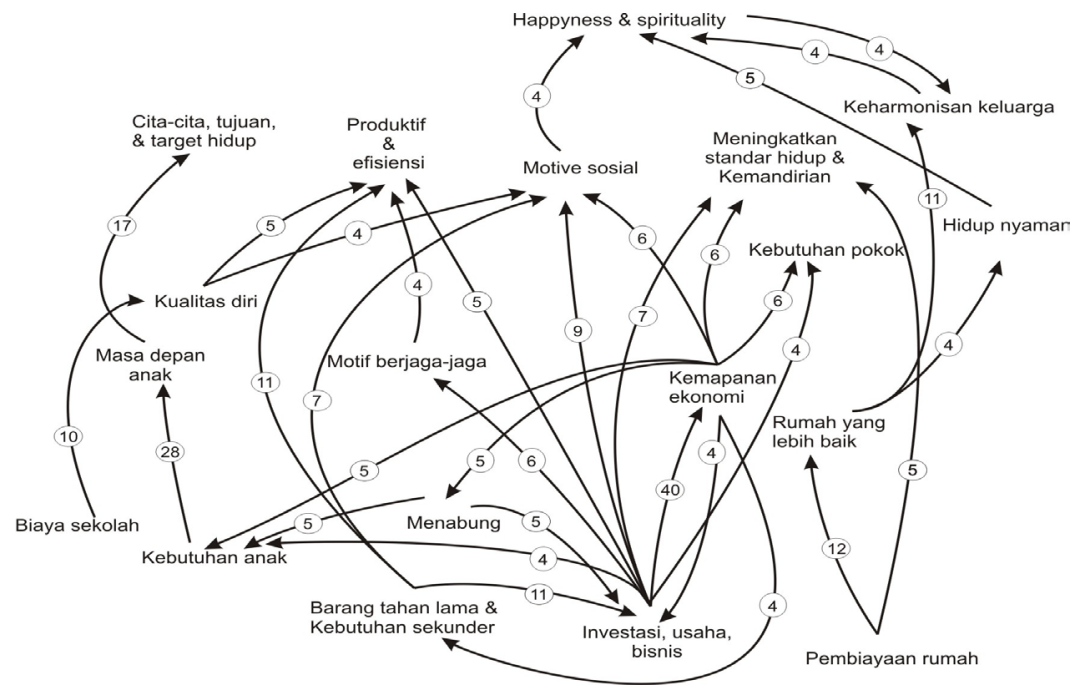

Gambar 8. Hierarchical goal map responden menerima hutang (HGM 1)

Gambar HGM 1 merupakan struktur sistem tujuan dari responden yang menerima tawaran hutang. Investasi merupakan tujuan yang paling banyak menjadi asal dari berbagai tujuan di atasnya. Pada gambar terlihat investasi menjadi asal dari tujuh tujuan di atasnya. Dari ketujuh tujuan yang menjadi sasaran investasi terlihat bahwa kemapanan ekonomi merupakan tujuan yang paling kuat terkait dengan investasi (40). Hal ini menunjukkan bahwa tujuan utama dari kegiatan invetasi adalah dalam rangka kemapanan ekonomi. Kemapanan ekonomi juga merupakan tujuan yang paling banyak menjadi asal dari tujuan lainnya. Hal ini memperlihatkan bahwa dengan kemapanan ekonomi banyak hal dan tujuan yang bisa dicapai.

Adapun tujuan yang paling sering menjadi sasaran dari tujuan-tujuan yang lain adalah produktif $\mathcal{E}$ efisien, motif sosial, meningkatkan standar hidup E kemandirian, kebutuhan anak, dan investasi. Tingkat hubungan antar tujuan yang paling tinggi adalah antara investasi dan kemapanan ekonomi yang memiliki tingkat hubungan sebesar 40, diikuti oleh kebutuhan anak $\rightarrow$ masa depan anak (28), masa depan anak $\rightarrow$ target hidup (17), pembiayaan rumah $\rightarrow$ rumah yang lebih baik (12), rumah yang lebih baik $\rightarrow$ keharmonisan keluarga (11), barang tahan lama $\rightarrow$ investasi (11), danSekotahl-æikualitas diri (10). 


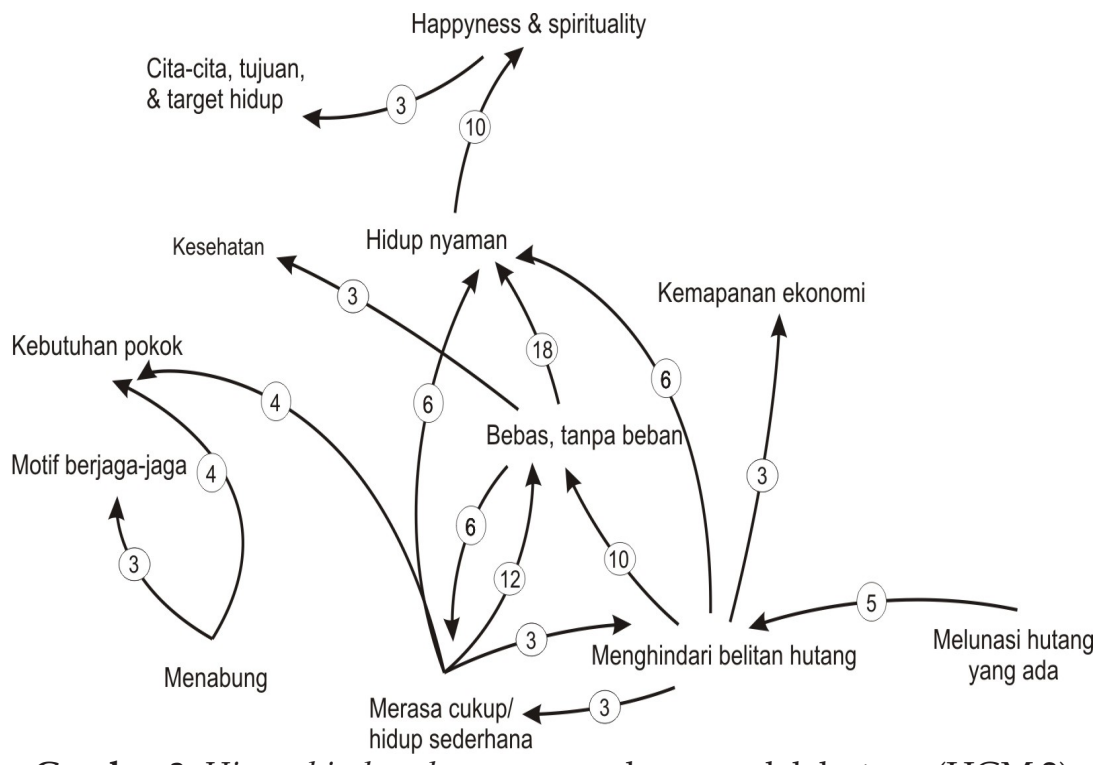

Gambar 3. Hierarchical goal map responden menolak hutang (HGM 2)

Melunasi hutang dilakukan dalam rangka untuk menghindari belitan hutang yang mana terlihat pada gambar, kedua tujuan ini terhubung secara langsung dengan tingkat frekuensi 5. Mengindari belitan hutang dan merasa cukup $\mathcal{E}$ hidup sederhana secara dominan terhubung secara langsung dengan keinginan untuk hidup bebas tanpa beban dengan masing-masing kekuatan hubungan 10 dan 12. Pada tingkatan selanjutnya, tujuan untuk hidup bebas tanpa beban secara dominan menuju pada tujuan untuk kenyamanan hidup yang ditunjukkan dengan tingkat kekuatan hubungan sebesar 18. Terakhir tujuan untuk kenyamanan hidup menuju pada tujuan kebahagiaanEspiritualitas sebanyak 10 kali. KebahagiaanEspritualias masih menunju tingkatan selanjutnya, tapi memiliki tingkat hubungan yang cukup kecil yaitu hanya 3. Dari gambar dapat disimpulkan bahwa tujuan-tujuan yang dimiliki responden menolak hutang cukup sederhana. Tingkat hubungan antar tujuan yang paling tinggi adalah antara bebas tanpa beban $\rightarrow$ hidup nyaman (18). Berikutnya diikuti oleh: merasa cukup/hidup sederhana $\rightarrow$ bebas tanpa beban (12), menghindari belitan hutang $\rightarrow$ bebas tanpa beban (10), dan hidup nyaman $\rightarrow$ kebahagiaan Espiritualitas (10).d with

\section{n nitro $^{\text {PDF }}$}




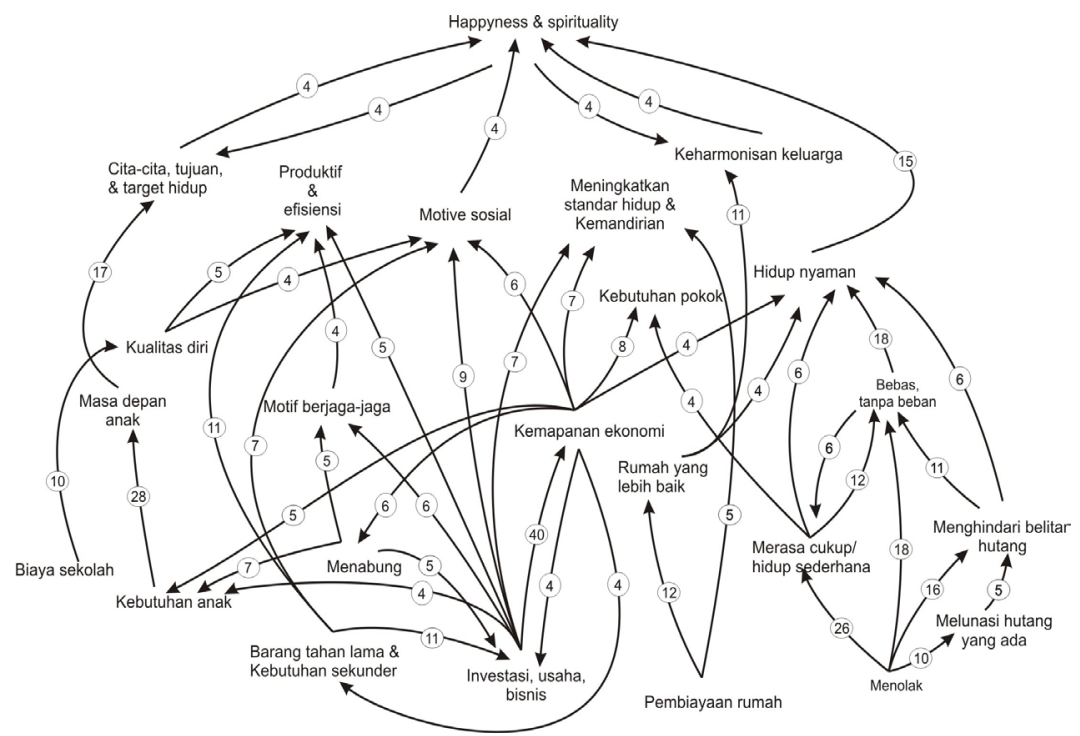

Gambar 4. Hierarchical goal map keseluruhan responden (HGM 3)

Pada HGM secara keseluruhan tidak terlihat perubahan yang berarti dibandingkan secara terpisah. Di bagian kanan secara khusus merupakan tujuan-tujuan yang dimiliki responden yang menolak dan bagian kiri merupakan tujuan-tujuan responden yang menerima. Hanya terdapat 4 tujuan yang sama-sama dituju oleh responden yang menerima maupun menolak yaitu kenyamanan hidup, kebutuhan pokok, happyness Espirituality, dan cita-cita hidup. Kenyamanan hidup secara dominan dituju oleh mereka yang menolak hutang yang mana dituju oleh 3 tujuan sebanyak 30 kali. Sedangkan dari yang menerima hanya sebanyak 8 kali oleh dua tujuan. Kebutuhan pokok dituju oleh responden yang menerima sebanyak 8 kali, dan 4 kali oleh yang menolak. Terdapat hubungan langsung antara kenyamanan hidup dan happnessesspirituality dengan tingkat hubungan sebesar 15. Namun apabila dilihat secara terpisah, tingkat hubungan hanya 5 pada HGM1 dan 10 pada HGM2. Hal ini memperlihatkan bahwa keterkaitan antara kenyamanan hidup dan happynessEspirituality lebih didominasi oleh mereka yang menolak. Pada gambar HGM3, terlihat hubungan timbal balik antara target hidup dan happyness $\mathcal{E}$ spirituality. Keterkaitan ini merupakan keterkaitan tujuan yang dimiliki oleh responden yang menolakıaKarenta apabila dilihat secara terpisah, 
tidak terjadi keterkaitan antar dua tujuan ini pada HGM responden yang menerima.

Untuk melihat peran suatu tujuan dalam sistem tujuan digunakan penghitungan index prominence. Terdapat 4 sifat atau peran tujuan yang akan dilihat dari hasil penghitungan index prominence yaitu abstractnesss (A), prestige (P), centrality (C), dan instrumentality (I). Tabel 2 merupakan tabel index prominence responden yang menerima hutang sedangkan tabel 3 adalah tabel index prominence responden yang menolak hutang. Pada responden yang menolak hutang terdapat beberapa tujuan yang tidak ditampilkan karena mempunyai tingkat hubungan yang rendah sehingga nilai index prominence yang muncul tidak proporsional.

Abstractness merupakan seberapa besar tingkat suatu tujuan sebagai super-ordinate goal atau terminal goal. Semakin tinggi nilai abstractness maka akan semakin tinggi peran suatu tujuan sebagai super-ordinate goal dalam sistem tujuan. Nilai abstractness didapatkan dari hasil: in-degrees / outdegress+in-degrees yang ada pada implication matrix.

Tabel 2. Index prominence responden menerima hutang

\begin{tabular}{rcccc}
\hline No. Tujuan & A & P & C & W \\
\hline 1 Investasi, usaha, bisnis & 0.26 & $\mathbf{0 . 0 7}$ & $\mathbf{0 . 2 6}$ & $\mathbf{0 . 1 9}$ \\
2 Pembiayaan rumah & 0.15 & 0.01 & 0.08 & $\mathbf{0 . 0 6}$ \\
3 Barang tahan lama \& & 0.11 & 0.01 & 0.10 & $\mathbf{0 . 0 9}$ \\
$\quad \begin{array}{l}\text { kebutuhan sekunder } \\
\text { 4 Membiayai kebutuhan }\end{array}$ & 0.36 & 0.04 & 0.10 & $\mathbf{0 . 0 7}$ \\
$\quad$ anak & & & & \\
5 Biaya Sekolah & 0.15 & 0.00 & 0.03 & 0.02 \\
6 Menabung & 0.45 & 0.03 & 0.07 & 0.04 \\
7 Kemapanan ekonomi & 0.49 & $\mathbf{0 . 1 1}$ & $\mathbf{0 . 2 3}$ & $\mathbf{0 . 1 2}$ \\
8 Rumah yang lebih baik & 0.39 & 0.03 & 0.07 & 0.04 \\
9 Kualitas diri & $\mathbf{0 . 6 1}$ & 0.05 & 0.08 & 0.03 \\
10 Keharmonisan keluarga & $\mathbf{0 . 6 7}$ & 0.05 & 0.07 & 0.02 \\
11 Produktif dan efisien & $\mathbf{0 . 7 5}$ & $\mathbf{0 . 1 0}$ & $\mathbf{0 . 1 3}$ & 0.03
\end{tabular}


12 Berjaga-jaga (being

$\begin{array}{llll}0.50 & 0.03 & 0.06 & 0.03\end{array}$ prepared)

13 Meningkatkan standar hidup \& kemandirian

14 Masa depan anak

$\begin{array}{llll}0.58 & 0.06 & \mathbf{0 . 1 0} & 0.04\end{array}$

15 Kebutuhan pokok

$\begin{array}{llll}0.58 & \mathbf{0 . 0 7} & \mathbf{0 . 1 2} & 0.05\end{array}$

16 Kesehatan, keamanan, rekreasi

17 Motif social $\begin{array}{llll}0.59 & 0.04 & 0.07 & 0.03\end{array}$

18 Mewujudkan cita-cita, tujuan, \& target hidup

19 Kewajiban

$\begin{array}{lllll} & 0.69 & 0.02 & 0.03 & 0.01\end{array}$

20 Kenyamanan hidup

$\begin{array}{llll}0.66 & 0.07 & 0.10 & 0.04\end{array}$

21 Kebahagiaan \& spiritualitas

$\begin{array}{lllll}0.76 & 0.06 & 0.08 & 0.02\end{array}$

$\begin{array}{llll}0.56 & 0.02 & 0.04 & 0.02\end{array}$

$\begin{array}{lllll}0.73 & 0.05 & 0.07 & 0.02\end{array}$

$\begin{array}{lllll}0.76 & \mathbf{0 . 0 6} & 0.08 & 0.02\end{array}$

Pada responden yang menerima tawaran hutang, terdapat empat tujuan yang memiliki nilai abstractness tertinggi yaitu kebahagiaanEspirituality (0.76), mewujudkan cita-cita (0.76), produktifEefisein (0.75), dan kenyamanan hidup (0.73). Keempat tujuan ini dapat digolongkan sebagai super-ordinate goal atau terminal goal dari perilaku berhutang. Berikutnya terdapat tujuan-tujuan yang mempunyai nilai berkisar antara 0. 39 - 0.69 yang mana dapat digolongkan sebagai focal goal dari responden yang menerima hutang. Tujuan-tujuan focal goal ini antara lain sebagai berikut yang diurutkan berdasarkan nilai abstractness: kesehatan, keamanan, rekreasi (0.69); motif sosial (0.66), masa depan anak (0.58), meningkatkan masa depanE kemandirian (0.58), kewajiban (0.56), berjaga-jaga (0.50), kemapanan ekonomi (0.49), menabung (0.45), dan rumah yang lebih baik (0. 39). Terakhir, terdapat 5 tujuan yang memiliki nilai abstractness paling rendah yang berkisar antara $0.11-0.36$. Kelima tujuan ini dapat digolongkan sebagai action goal atau tujuan yang paling konkrit dari responden yang menerima hutang. Kelima tujuan tersebut antara lain: barang tahan lama\&kebutuhan sekunder (0.11), pembiayaan rumah (0.15), biaya sekolah (0.15), investasi (0.26), dan membiayai kebutuhan anak (0.36).

Pada respondencyang menolak hutang terdapat tujuan yang memiliki nilai abstractnece tertinggi yaitu KSHFigianEspixitualitas 
(0.85). Tujuan-tujuan lain yang mempunyai nilai abstractness berkisar 0.06 - 0.67 dapat digolongkan sebagai tujuan focal goal dari responden yang menolak hutang. Sedangkan aktivitas menolak hutang pada responden ini dapat digolongkan langsung sebagai action goal. Karena pada intrumen penelitian responden yang menolak hutang langsung diminta untuk mengisikan jawaban pada pertanyaan 2 atau focal goal. Jadi aktivitas menolak hutang langsung digolongkan sebagai action goal.

Tabel 3. Index prominence responden menolak hutang

\begin{tabular}{rlllll}
\hline No. & Tujuan & $\mathbf{A}$ & $\mathbf{P}$ & $\mathbf{C}$ & $\mathbf{I}$ \\
\hline 1 Menabung & 0.31 & 0.02 & 0.07 & 0.05 \\
2 Kemapanan ekonomi & 0.53 & 0.05 & 0.09 & 0.04 \\
3 Keharmonisan keluarga & 0.60 & 0.02 & 0.03 & 0.01 \\
4 Kebutuhan pokok & 0.62 & $\mathbf{0 . 0 7}$ & 0.12 & 0.05 \\
5 Kesehatan, keamanan, & 0.67 & 0.02 & 0.03 & 0.01 \\
$\quad$ rekreasi & & & & \\
6 Mewujudkan cita2, tujuan, \& & 0.56 & 0.03 & 0.05 & 0.02 \\
$\quad$ target hidup & & & & \\
7 Kewajiban/Obidience & 0.50 & 0.02 & 0.03 & 0.02 \\
8 Kenyamanan hidup & 0.67 & $\mathbf{0 . 2 1}$ & $\mathbf{0 . 3 1}$ & $\mathbf{0 . 1 0}$ \\
9 Kebahagiaan \& spiritualitas & $\mathbf{0 . 8 5}$ & $\mathbf{0 . 1 0}$ & 0.11 & 0.02 \\
10 Merasa cukup dan hidup & 0.26 & $\mathbf{0 . 0 7}$ & $\mathbf{0 . 2 6}$ & $\mathbf{0 . 1 9}$ \\
$\quad$ sederhana & & & & \\
11 Menghindari belitan hutang & 0.30 & $\mathbf{0 . 0 7}$ & $\mathbf{0 . 2 4}$ & $\mathbf{0 . 1 7}$ \\
12 Melunasi hutang yang ada. & 0.06 & 0.01 & 0.10 & 0.09 \\
13 Bebas, tanpa beban (hassle free) & 0.48 & $\mathbf{0 . 1 7}$ & $\mathbf{0 . 3 6}$ & $\mathbf{0 . 1 9}$ \\
14 Others & 0.60 & 0.02 & 0.03 & 0.01 \\
\hline
\end{tabular}

Prestige menunjukkan seberapa sering tujuan menjadi sasaran dari tujuan lainnya. Semakin tinggi nilai prestige, semakin sering sebuah tujuan menjadi sasaran dari tujuan lainnya. Nilai prestige didapatkan dari in-degree / total cells. Pada responden yang menerima hutang, kemapanan ekonomi merupakan tujuan yang paling prestige dengan nilai 0.11 . Setelah kemapanan ekonomi, tujuan lain yang memiliki nilairpekstigeityang tinggi adalah: produktifEefisien 
(0.10), masa depan anak (0.07), motif sosial (0.07), dan investasi (0.07). Pada responden yang menolak hutang, tujuan yang paling sering dituju adalah kenyaman hidup dengan nilai perestige 0.21 . Terlihat di sini perbedaan antara mereka yang menerima dan menolak hutang. Pada responden yang menerima hutang tujuan yang sering dijadikan sasaran adalah kemapanan ekonomi sedangkan pada responden yang menolak hutang lebih mengutamakan kenyamanan hidup. Setelah kenyamanan hidup, tujuan yang memiliki nilai prestige tinggi pada responden yang menolak adalah bebas tanpa beban (0.17) serta kebahagiaan Espiritualitas (0.10).

Centrality adalah tingkat keterlibatan sebuah tujuan dengan berbagai tujuan dalam struktur sistem tujuan. Keterlibatan ini berarti bahwa suatu tujuan terlibat baik sebagai sasaran maupun asal dari tujuan yang lainnya. Semakin tinggi nilai centrality, maka semakin sering suatu tujuan menjadi sasaran atau sebagai asal dari tujuan lain. Rumusan untuk mendapatkan nilai centrality adalah: in-degress + outdegrees/total cells. Pada responden yang menerima tawaran hutang, investasi merupakan tujuan yang paling sentral dalam struktur sistem tujuan dengan nilai 0.26 . Berikutnya yang paling sentral kedua adalah kemapanan ekonomi dengan nilai 0.23 yang diikuti oleh produktif efisien (0.13) dan masa depan anak (0.12). Sedangkan pada responden yang menolak tawaran hutang, tujuan yang paling sentral adalah bebas tanpa beban (0.36), diikuti oleh kenyamanan hidup (0.31), merasa cukup, hidup sederhana (0.26) dan menghindari belitan hutang (0.24).

Instrumentality menunjukkan peran suatu tujuan sebagai instrumen untuk mencapai tujuan yang lainnya. Tingginya nilai instrumentality mengindikasikan bahwa suatu tujuan sering dijadikan alat atau cara dalam mencapai tujuan lain. Nilai instrumentality dihitung dari hasil: out-degress / total cells.Nilai instrumentality tertinggi pada struktur sistem tujuan responden yang menerima hutang ada pada investasi. Investasi mempunyai nilai 0.19 atau menyumbang $19 \%$ sebagai cara dalam mencapai tujuan-tujuan yang lainnya. Nilai tertinggi kedua yaitu 0.12 yang dimiliki oleh kemapanan ekonomi. Sedangkan pada responden yang menolak hutang, nilai instrumen yang paling tinggi dimiliki oleh merasa cukup, hidup sederhana dan bebas tanpa beban yang sama-sama mempunyai nilai 19, diikuti oleh menghindari belitan hutang (17), dan kenyamanan hidup (10).

\section{Created with}




\section{Diskusi}

Hasil analisis isi (content analysis) menghasilkan 26 kategori tujuan untuk konsumen yang menerima hutang dan 20 kategori tujuan untuk konsumen menolak hutang. Pada konsumen yang berhutang terdapat beberapa tujuan yang terkait langsung dengan alokasi penggunaan dana hutang. Tujuan-tujuan tersebut antara lain: investasi atau bisnis, membeli barang tahan \& kebutuhan sekunder, pembiayaan rumah, dan membiayai kebutuhan anak, biaya sekolah, dan menabung. Berdasarkan pembagian jenis hutang yang terdiri dari hutang konsumtif dan hutang produktif (Rivai, dkk., 2007), ditemukan bahwa alokasi penggunaan dana hutang lebih banyak digunakan untuk tujuan yang produktif yaitu investasi atau usaha, sekolah, menabung, dan pembiayaan anak. Meskipun demikian terdapat juga tujuan yang bersifat konsumtif antara lain membeli barang tahan lama\&kebutuhan sekunder. Namun yang menarik di sini adalah bahwa kebutuhan pokok sebagai kegiatan konsumtif tidak menjadi tujuan langsung dari penggunaan dan hutang. Pada penelitian Hidayat (2009), kebutuhan pokok merupakan tujuan cukup dominan yang terkait dengan alokasi windfall income atau pemasukan yang tak terduga. Hal ini mengindikasikan bahwa sumber dana yang didapatkan dari hutang tidak secara langsung dialokasikan untuk kebutuhan pokok. Temuan ini mendukung tesis yang diajukan Manning (2004) yang menyebutkan bahwa hutang tidak lagi menjadi sebuah perilaku dalam rangka memenuhi kebutuhan pokok atau kebutuhan yang mendesak. Namun dalam rangka memenuhi tujuan yang lebih tinggi yang ingin dicapai.

Tujuan-tujuan yang muncul yang terkait langsung dengan perilaku berhutang pada penelitian ini juga terdapat pada perilaku menabung. Bebarapa penelitian (Horioka \& Watanabe,1997; Hidayat, 2009; \& Sharon, dkk., 2007) menunjukkan investasi, kebutuhan sekunder \& barang tahan lama, membiayai kebutuhan anak, pembiayaan rumah, dan biaya sekolah juga merupakan tujuantujuan yang ada dibalik perilaku menabung. Menabung merupakan suatu tindakan yang didominasi oleh etika untuk menunda keinginan dengan menyimpan dan mengumpulkan uang, sedangkan hutang merupakan tindakan memenuhi keinginan secara langsung dengan menggunakan fasilitas pinjaman yang ada. Katona (1951) menyebutkan bahwa hutang dapat dikategorikan sebagai kondisi dissaving atau tabungan negatif. Dari perbandingan tujuan perilaku 
menabung dan berhutang yang memiliki kesamaan, mengindikasikan bahwa baik menabung dan berhutang merupakan instrumen atau cara yang berbeda yang ditempuh oleh konsumen dalam memenuhi tujuan yang diinginkan.

Berdasarkan peran suatu tujuan dalam sistem tujuan (yang didapatkan dari penghitungan index prominence), investasi dan kemapanan ekonomi merupakan tujuan yang paling central pada sistem tujuan konsumen yang berhutang, investasi dengan nilai centrality 0.26 dan kemapanan ekonomi sebesar 0.23 . Selain paling central kemapanan ekonomi mempunyai tingkat prestige yang tinggi $(\mathrm{P}=0.11)$ diikuti oleh tujuan produktif \& efisien $(\mathrm{P}=0,10)$ dimana menunjukkan bahwa kedua tujuan ini merupakan tujuan yang paling banyak dijadikan sasaran bagi tujuan-tujuan lain. Hal ini mengindikasikan bahwa motif di balik perilaku berhutang didominasi oleh tujuan-tujuan dalam rangka meningkatkan pendapatan dan tujuan produktif. Bandingkan dengan tujuan-tujuan yang konsumtif seperti membeli barang tahan lama yang hanya mempunyai nilai centrlality (0.10) dan prestige (0.01) atau pembiayaan rumah 0.01 dan 0.08. Temuan ini berbeda dengan asumsi klasik yang beranggapan kondisi berhutang terjadi ketika adanya kebutuhan atau pengeluaran yang tidak sesuai dengan pendapatan yang ada. Teori Keynes tentang konsumsi (dalam Katona 1951) menyebutkan bahwa kondisi berhutang terjadi ketika pengeluaran lebih besar dari pendapatan $(\mathrm{C}>\mathrm{Y})$. Asumsi ini lebih mengarah pada kondisi berhutang terjadi karena ingin menutupi kekurangan (hutang konsumtif). Sedangkan hutang produktif yang lebih dominan pada penelitian ini lebih mengarah pada kondisi berhutang karena ingin meningkatkan pendapatan.

Konsumen yang tidak ingin berhutang menunjukkan tujuan yang lebih sederhana dibandingkan dengan konsumen yang menerima hutang. Total tujuan yang muncul pada konsumen yang menolak hutang hanya 383 dan 176 hubungan antar tujuan yang mana jauh lebih sedikit dibanding mereka yang menerima hutang (720 tujuan dan 451 hubungan antar tujuan). Dinamika tujuan konsumen yang menolak hutang juga cukup sederhana (lihat gambar 3). Dinamika tujuan yang dimiliki konsumen yang menolak juga hanya seputar enam tujuan yang dominan yaitu kebebasan tanpa beban; merasa cukupEhidup sederhana; menghindari belitan hutang; melunasi hutang yang ada; kenyamanàn hidup; dan kebahagiaan \& spiritualitas. 
Tidak terdapat tujuan-tujuan yang bersifat konsumtif atau produktif pada responden yang menolak. Mereka yang menolak lebih memilih untuk menikmati pendapatan yang ada.

Tujuan yang paling sentral dari konsumen yang menolak hutang adalah bebas tanpa beban dengan nilai centrality 0.36 (lihat tabel 13). Sedangkan tujuan yang paling prestige adalah kenyamanan hidup $(\mathrm{P}=0.21)$. Hal ini sangat berbeda dengan responden yang menolak hutang yang mana tujuan sentralnya terkait dengan investasi dan kemapanan ekonomi, dan tujuan yang paling prestige adalah produktif \& efisien beserta kemapanan ekonomi. Perbedaan ini menunjukkan bahwa responden yang menolak hutang mempunyai sistem tujuan yang sederhana yang terkait seputar keinginan untuk hidup nyaman, bersyukur, tanpa beban, dan kebahagiaan hidup. Sedangkan responden yang berhutang menunjukkan sistem tujuan yang lebih kompleks. Pada tingkatan terminal goal kedua kelompok responden juga mempunyai perbedaan yang cukup signifikan. Pada responden yang menolak hutang tujuan yang menjadi terminal goal adalah kebahagiaan\& spiritualitas. Sedangkan pada responden yang menerima hutang, produktif\&efisien menjadi terminal goal yang dominan yaitu tujuan yang mempunyai nilai abastractness tinggi dan banyak dijadikan sasaran oleh tujuan-tujuan di bawahnya.

Perbandingan sistem tujuan antara responden yang menerima dan menolak hutang di atas memperlihatkan bahwa skema kognitif responden yang menerima dan menolak hutang cukup berbeda, meskipun terdapat beberapa tujuan yang dijadikan tujuan bersama. Dalam model hierarki motif Huffman, dkk. (2000), tujuan yang sentral dalam sistem tujuan dapat disamakan dengan life project atau suatu tujuan yang dijadikan tujuan kunci dalam hidup, sedangkan terminal goal dapat disamakan dengan life themes atau tema hidup yang dijadikan sebagai tujuan hidup yang ideal bagi individu dalam kehidupan. Jadi, life project dari responden yang menerima hutang didominasi keinginan untuk mempunyai kemapanan ekonomi, sedangkan responden yang menolak hutang didominasi oleh keinginan untuk hidup bebas tanpa beban. Tema hidup dari kedua responden juga berebada, responden berhutang mempunyai tema hidup tentang produktif\&efisien, sedangkan responden menolak hutang terkait dengan kenyamanan hidup. Tujuan-tujuan di balik perilaku berhutang didominasi oleh tujuan-tujuan yang produktif seperti ivestasi dan kemâpanan with ekonomi. Hal ini mengindikasikan 
bahwa berhutang merupakan instrumen dalam rangka mencapai kesejahteraan ekonomi. Hal ini sejalan dengan perhitungan ekonomi makro yang menyebutkan bahwa kredit berkorelasi dengan pertumbuhan ekonomi dan kesejahteraan masyarakat (Indiastuti, 2010).

Dari variabel demografi menunjukkan beberapa variabel yang signifikan dapat membedakan pilihan menerima atau menolak hutang yaitu usia, pekerjaan, dan pernah berhutang atau tidak selama sepuluh tahun terakhir. Variabel usia secara signifikan membedakan piliahan menerima atau menolak hutang dengan nilai chi-square $0.031<0.05$. Kelompok usia di bawah 35 tahun mempunyai kecenderungan berhutang yang paling tinggi, diikuti oleh usia 35-55 tahun, dan yang mempunyai kecenderungan berhutang yang paling rendah adalah kelompok umur diatas 55 tahun. Temuan ini sejalan dengan life cycle theory (dalam Boyes, 1984) yang berasumsi bahwa individu meratakan tingkat konsumsinya dengan menggunakan kekayaan secara akumulatif sepanjang rentang kehidupan. Masa awal kehidupan (masa awal karir) orang akan cenderung berhutang untuk menutupi kebutuhannya. Pada masa kemapanan karir orang sudah mulai mempunyai pendapatan yang mapan dan mulai menabung untuk masa pensiun. Sedangkan pada akhir-akhir masa karir individu lebih cenderung menggunakan tabungannya. Temuan pada penelitian ini, pada usia mendekati pensiun kecenderungan berhutang paling rendah dibandingkan dengan usia-usia sebelumnya. Asumsi life cycle theory juga sejalan dengan temuan penelitian pada variabel status pekerjaan. Status pekerjaan apakah PNS, honorer atau guru swasta secara signifikan membedakan pilihan menerima atau menolak tawaran hutang (chi-square $=0.008<0.05$ ). Honorer yang mana merupakan tahapan awal karir mempunyai kecenderungan berhutang yang tinggi dibandingkan dengan guru yang berstatus PNS yang mana sudah mempunyai pendapatan yang cukup stabil.

Variabel demografi lainnya yang berpengaruh terhadap pilihan menerima atau menolak hutang yaitu pernah berhutang atau tidak (chi-square $=0.007<0.05$ ). Individu yang tidak pernah berhutang dalam sepuluh tahun terakhir $85.7 \%$ menolak tawaran hutang, sedangkan individu yang pernah berhutang sebelumnya 53.3\% menerima atau hampir sebagian menerima dan sebagian menolak. Individu yang tidak pernah berhutang dalam sepuluh terakhir disebabkan oleh faktor sikap. Wi Penelitian Prasadjaningsih (1998) 
menunjukkan bahwa sikap seseorang terhadap hutang berpengaruh terhadap pilihan berhutang atau tidak dan juga berpengaruh terhadap tingkat keseringan berhutang. Studi Watson (1998) juga menunjukkan bahwa sikap terhadap hutang berpengaruh terhadap jumlah besaran hutang seseorang. Jadi pernah berhutang atau tidak yang membedakan pilihan berhutang atau menolak berdasarkan penelitian terdahulu dapat dikarenakan karena sikap seseorang terhadap hutang.

\section{Kesimpulan}

Dari penelitian ini dapat disimpulkan bahwa terdapat perbedaan sistem tujuan konsumen yang berhutang dan konsumen yang menolak hutang. Sistem tujuan konsumen yang berhutang terdiri tujuan-tujuan yang kompleks yang berisikian tujuan-tujuan yang produktif maupun konsumtif. Sedangkan pada konsumen yang menolak hutang, sistem tujuan yang ada cukup sederhana dan isi dari sistem tujuan terdiri dari tujuan-tujuan yang cenderung menerima akan keadaan yang sudah ada. Struktur hierarkis dari konsumen menerima hutang berangkat dari action goal (aktivitas yang dilakukan dengan dana hutang) yang terdiri dari: investasi, membeli barang tahan lama, pembiayaan rumah, pembiayaan anak, dan biaya sekolah. Aktivitas-aktivitas tersebut dilakukan dalam rangka memenuhi tujuan yang lebih tinggi, focal goal yang terdiri dari tujuan-tujuan untuk kemapanan ekonomi, meningkatkan kualitas diri, masa depan anak, meningkatkan standar hidup, kemandirian, dan kepemilikan rumah yang layak atau lebih baik. Sedangkan tujuan yang menjadi terminal goal atau super-ordinate goal dari konsumen yang berhutang didominasi oleh tujuan produktif dan efisien, diikuti tujuan-tujuan lain seperti mewujudkan cita-cita, motif sosial, keharmonisan keluarga, dan kebahagiaan\&spiritualitas. Pada konsumen tidak berhutang dinamika hierarki tujuan dimulai dari action goal berupa tindakan menolak hutang, kemudian diikuti focal goal yang terdiri dari: melunasi hutang yang ada, merasa cukup \& hidup sederhana, menghindari belitan hutang, bebas tanpa beban, dan kenyamanan hidup. Sedangkan yang menjadi terminal goal konsumen yang tidak berhutang didominasi oleh tujuan untuk kebahagiaan \& spiritualitas.

Dari variabel demografi dapat disimpulkan bahwa terdapat tiga variabel dalam penelitian ini $_{\text {y }}$ yang dapat membedakan konsumen yang menerima dan menolak Ketiga p̧riłbel tersebut adalah 
usia, status pekerjaan, dan pernah berhutang atau tidak dalam sepuluh tahun terakhir. Berdasarkan usia, dapat disimpulkan bahwa semakin tua responden, maka kecenderungan berhutang semakin rendah, sebaliknya semakin muda semakin mempunyai kecenderungan menerima hutangnya tinggi. Berdasarkan status pekerjaan menunjukkan bahwa honorer mempunyai kecenderungan berhutang yang lebih tinggi dari pegawai negeri sipil (PNS). Kedua variabel ini sejalan dengan teori life cycle yang membedakan tiga tahapan kehidupan berdasarkan pendapatan dan masa kerja. Pada masa awal karir (early years) dimana individu baru memulai karir dan pendapatannya masih rendah, individu tersebut mempunyai kecenderunganberhutangyang tinggiuntukmenutupikebutuhannya. Sedangkan pada masa pertengahan, orang sudah mulai mapan dan kecenderungan berhutang menurun dan mulai menabung untuk masa pensiun. Sedangkan pada masa pensiun, individu menggunakan tabungan yang dilakukan pada masa pertengahan untuk membiayai kebutuhan hidupnya. Pernah berhutang atau tidak dalam sepuluh tahun terakhir sangat membedakan pilihan berhutang atau tidak pada responden penelitian ini. Mereka yang tidak pernah berhutang sama sekali dalam sepuluh tahun terakhir mayoritas menolak tawaran berhutang. Sedangkan mereka yang pernah berhutang, hampir sebagian menerima dan sebagian menolak. Kecenderungan ini bisa dipengaruhi karena sikap terhadap hutang. Karena berdasarkan penelitian sebelumnya (Prasadjaningsih, 1998 \& Watson, 1998) menunjukkan bahwa sikap berpengaruh terhadap pilihan berhutang atau tidak, tingkat keseringan berhutang, dan tingginya jumlah hutang.

Adapun saran dari hasil penelitian ini adalah:

Bagi lembaga penyalur kredit, hasil penelitian ini menunjukkan bahwa tujuan-tujuan di balik perilaku berhutang didominasi oleh tujuan-tujuan yang produktif seperti ivestasi dan kemapanan ekonomi. Hal ini mengindikasikan bahwa berhutang merupakan instrumen dalam rangka mencapai kesejahteraan ekonomi. Untuk meningkatkan kesejahteraan ekonomi masyarakat, hendaknya lembaga-lembaga keuangan mempermudah syarat-syarat kredit yang bersifat produktif dan memberikan pendidikan tentang kredit terhadap masyarakat.

Bagi konsumen yang akantmenggunakan fasilitas pinjaman, hendaknyabenar-benarmemikirkantujuan-tuibßz) 
dengan cara berhutang. Tujuan-tujuan yang bersifat produktif seharunya direncanakan dengan teliti, agar dana pinjaman yang digunakan benar-benar menghasilkan untuk kemapanan ekonomi. Untuk tujuan-tujuan yang konsumtif, juga harus dipertimbangkan apakah tujuan-tujuan tersebut memang diperlukan atau tidak. Karena hutang yang tidak direncanakan akan menyebabkan kredit macet dan akan berdampak pada kesehatan mental.

Untuk penelitian selanjutnya hendaknya mengungkap struktur tujuan perilaku berhutang yang mengarah pada jenis hutang yang lebih spesifik seperti hutang dengan kartu kredit, koperasi, pegadaian, dan bank. Spesifikasi ini akan lebih mengungkap tujuan di balik kecenderungan konsumen terhadap instrument keuangan tertentu dalam membiayai kebutuhan hidup dengan cara berhutang. Dengan spesifikasi tersebut akan memberi manfaat dan informasi yang lebih khusus terhadap lembaga keuangan.

Metode laddering dirancang untuk mengungkap motif hierarkis di balik perilaku tertentu. Hasil penelitian ini menunjukkan bahwa metode ini sangat beresesuaian dengan konstruk teori sistem tujuan yang bersifat hierarkis. Bagi penelitian-penelitian selanjutnya, metode ini dapat digunakan dalam berbagai konteks keperluan seperti dalam setting organisasi, klinis, dan pendidikan. Penelitian selanjutnya yang akan menggunakan teknik laddering hendaknya menyusun angket laddering yang lebih sederhana. Karena dengan jumlah pertanyaan laddering yang terlalu banyak akan membuat responden jenuh dalam menjawab angket.

\section{Daftar Pustaka}

Alhassan G., Abdul-Muhmin, A. G. A., \& Umar, Y. A. (2007). Credit card ownership and usage behaviour in Saudi Arabia: The impact of demographics and attitudes toward debt. Journal of Financial Services Marketing, 12, 219 - 234.

Azwar, S. (2007). Metode penelitian. Yogyakarta: Pustaka Pelajar.

Bagozzi, R.P., \& Dholakia, U. (1999). Goal setting and goal striving in consumer behavior. Journal of Marketing, 63, 19-32.

Bagozzi, R.P., Bergami, Mc, \&\&Ledne,th. (2003). Hierarchical representation of

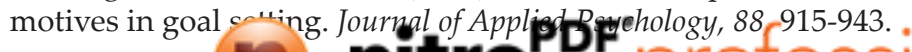


Bappenas. (2009) Penyebab dan dampak krisis keuangan global. Buku pegangan penyelenggaraan pemerintah dan pembangunan daerah.

Boyes, W. J. (1984). Macroeconomics: The dynamics of theory and policy. Cincinnati, Ohio: South-Western Publishing.

Carver, C.S. (2003). Self-regulation. In. A. Tesser \& N. Schwarz (Eds.), Blackwell handbook of social psychology: Individual processes (pp. 307328). Oxford, UK: Blackwell Publishing.

Carver, C.S. \& Scheier, M.F. (1998). On the self-regulation of behavior. Cambridge: Cambridge University Press.

Hidayat, R. (2009) Generic goal system: Content, structure, and determinants of goals at the generic level. Yogyakarta:Tiara Wacana.

Horioka, C.Y., \& Watanabe, W. (1997) Why do people save? A micro-analysis of motives for household saving in Japan. Economic Journal, 107 537-552.

Huffman, C., Ratneshwar, S., \& Mick, D.G. (2000). Consumer goal structures and goal-determination processes: An integrative framework. In S. Ratneshwar, D.G., Mick, \& C. Huffman (Eds.), The why of consumption (pp. 9-35). London: Routledge.

Indiastuti, R. (2010) Perbaikan kredit untuk pertumbuhan kredit dan kinerja bisnis. Economic Review, 219, 1-9.

Job, V. \& Brandstätter, V. (2009). Get a taste of your goals: Promoting motivegoal congruence through affect-focus goal fantasy. Journal of Personality, 77, 1527-1560.

Katona, G. (1951). Psychological analysis of economic behavior. New York: McGraw-Hill.

Kruglanski, A.W., Shah, J.Y., Fishbach, A., Friedman, R., Chun, W.Y., \& Sleeth-Keppler, D. (2002). A theory of goal systems. Advances in Experimental Social Psychology, 34, 331-378.

Lea, S.E.G., Webley, P., \& Walker, C.M. (1995). Psychological factors in consumer debt: Money management, time horizon and consumer behavior. Journal of Economic Psychology, 16, 681-701.

Manning, R.D. (2004) Globalization and the international expansion of consumer debt: The political economy of credit card world. Conference Papers, Annual Meeting, American Sociological Association.

\section{Created with}


Neimeyer, R. A., Anderson, A., \& Stockton, L. (2001). Snakes versus ladders: A validation of laddering technique as a measure of hierarchical structure. Journal of Constructivist Psychology, 14, 85-105.

Nyhus, E.K. \& Webley, P. (2001). The role of personality in household saving and borrowing behavior. European Journal of Personality, 15, 85103.

Pieters, R., Baumgartner, H., \& Allen, D. (1995). A means-end chain approach to consumer goal structures. International Journal of Research in Marketing, 12, 227-224.

Prasadjaningsih, M. O. (1998). Pengaruh gaya hidup, nilai, kepribadian, sikap terhadap pilihan perilaku berhutang, Sebuah kajian lapangan. Tesis, Program Pascasarjana Psikologi, UI, Tidak diterbitkan.

Reynolds, T. J., \& Gutman, J. (1988). Laddering theory, method, analysis, and interpretation. Journal of Advertising Research, 11-31.

Rivai, V. H., Veithzal, A. P., \& Idroes, F. N. (2007). Bank and financial institution management: Conventional \& syariah system. Jakarta: P.T. Rajagrafindo Persada.

Sharon, A.D, Sophia T.A \& Stacy E.W. (2007) Household savings motives. The Journal of Consumer Affairs, 41, 174-186.

Wang, J., \& Xiao, J.J. (2009). Buying behavior, social support and credit card indebtedness of college students. International Journal of Consumer Studies, 33, 2-10.

Watson, J. J. (1998). Materialism and debt: A study of current attitudes and behaviors. Advances in Consumer Research, 25, 203-207.

\section{Created with}

